\title{
The Impact of the Lisbon Football Derby on the Profile of Emergency Department Admissions
}

\author{
O Impacto do Derby de Futebol Lisboeta no Perfil de Admissões a um \\ Serviço de Urgência
}

André ALMEIDA ${ }^{1}$, Mónica EUSÉBIO², Jaime ALMEIDA³ ${ }^{3}$ Matteo BOATTINI ${ }^{1}$

Acta Med Port 2014 Nov-Dec;27(6):700-703

\section{ABSTRACT}

Background: Variations in emergency department admissions have been reported to happen as a result of major sports events. The work presented assessed changes in volume and urgency level of visits to a major Emergency Department in Lisbon during and after the city's football derby.

Material and Methods: Volume of attendances and patient urgency level, according to the Manchester Triage System, were retrospectively analyzed for the 2008-2011 period. Data regarding 24-hour periods starting 45 minutes before kick-off was collected, along with data from similar periods on the corresponding weekdays in the previous years, to be used as controls. Data samples were organized according to time frame (during and after the match), urgency level, and paired accordingly.

Results: A total of 14 relevant periods (7 match and 7 non-match) were analyzed, corresponding to a total of 5861 admissions. During the match time frame, a $20.6 \%$ reduction $(p=0.06)$ in the total number of attendances was found when compared to non-match days. MTS urgency level sub-analysis only showed a statistically significant reduction $(26.5 \% ; p=0.05)$ in less urgent admissions (triage levels green-blue). Compared to controls, post-match time frames showed a global increase in admissions $(5.6 \% ; p=0.45)$, significant only when considering less urgent ones $(18.9 \% ; p=0.05)$.

Discussion: A decrease in the total number of emergency department attendances occurred during the matches, followed by a subsequent increase in the following hours. These variations only reached significance among visits triaged green-blue.

Conclusion: During major sports events an overall decrease in emergency department admissions seems to take place, especially due to a drop in visits associated with less severe conditions.

Keywords: Emergency Service, Hospital; Triage; Sports; Soccer; Portugal.

\section{RESUMO}

Introdução: Está descrita a ocorrência de variações nas admissões ao serviço de urgência como resultado de eventos desportivos importantes. O estudo que apresentamos avaliou mudanças no volume e tipo de visitas a um serviço de urgência central de Lisboa durante e após o derby futebolístico da cidade.

Material e Métodos: Analisámos retrospectivamente o volume de admissões e a categoria de urgência atribuída pela Triagem de Manchester, de 2008 a 2011. Recolhemos dados relativos a períodos de 24 horas com início 45 minutos antes dos jogos, assim como dados relativos a períodos semelhantes nos dias da semana correspondentes dos anos anteriores, para controlo. Organizaram-se os dados por espaços temporais (durante e pós-jogo) e categoria de urgência, após o que se emparelharam.

Resultados: Analisaram-se 14 períodos (sete com jogo e sete sem jogo) e um total de 5861 admissões. Durante o jogo verificou-se uma redução de 20,6\% $(p=0,06)$ no número total de admissões face aos dias controlo. Na sub-análise das categorias da Triagem de Manchester a redução foi estatisticamente significativa $(26,5 \% ; p=0,05)$ apenas nas admissões menos urgentes (categorias verdeazul). Comparado com o controlo, o pós-jogo mostrou um aumento global do número de admissões $(5,6 \% ; p=0,45)$, significativo somente quando consideradas as menos urgentes $(18,9 \% ; p=0,05)$.

Discussão: Durante os jogos o número total de admissões ao serviço de urgência sofreu um decréscimo, ocorrendo nas horas subsequentes um aumento das mesmas. Estas variações só foram significativas nas categorias de triagem verde-azul.

Conclusão: Durante eventos desportivos importantes parece dar-se uma redução nas admissões ao serviço de urgência, sobretudo devido a uma diminuição das visitas associadas a situações menos graves.

Palavras-chave: Serviço de Urgência Hospitalar; Triagem; Desporto; Futebol; Portugal.

\section{INTRODUCTION}

Large sporting events have the notorious capacity of attracting large crowds into match venues as well as drawing the attention of many to view live televised broadcasts. Studies analyzing the impact of these events on the number and type of emergency department (ED) attendances in several countries with a developed health care system have yielded mixed results. The first major such study, covering the American Football Super Bowl finals from 1988 to 1992, found a significant decrease in attendances during broadcasts. This decline was more pronounced when the local team was one of the competitors. ${ }^{1}$ Most of the following research performed on other countries pointed to similar conclusions, ${ }^{2-8}$ although in some of these studies the findings were limited to a statistically non-significant trend. ${ }^{2,4,5}$ In contrast, one single study carried out in Spain found an increase in attendances during football match. It is however noteworthy that this last study was conducted in an extra-hospital ED based in a rural area, as opposed to the

1. Unidade Funcional de Medicina 4. Centro Hospitalar de Lisboa Central. Lisboa. Portugal.

2. Unidade de Saúde Pública Internacional e Bioestatística. Instituto de Higiene e Medicina Tropical. Lisboa. Portugal.

3. Department of Neuroscience. Erasmus MC University Hospital. Rotterdam. The Netherlands.

Recebido: 08 de Novembro de 2013 - Aceite: 26 de Março de 2014 | Copyright $\odot$ Ordem dos Médicos 2014 
urban hospital setting where most of the former investigations took place. ${ }^{9}$ Some studies have also focused on the hours following match events, with a few showing a modest increase in volume of admissions..$^{3-4,12}$ This increase is explained by the authors as being due to a rebound effect of visits which had been delayed during match duration as well as due to a rise in casualties related to alcohol misuse and violence, a phenomenon which might be expressive in some geographical and cultural contexts. ${ }^{4,10-12}$

No such study was ever conducted in Portugal. Besides, none of the cited works focused in the type of admissions most affected by these variations as far as urgency level is concerned, using a quantifiable measure.

The twice-yearly Portuguese First League encounter between Lisbon's major football clubs Sporting C.P. and S.L. Benfica, is the city's main regular sporting event with the highest public turn-out and television audience. We aimed to assess the impact of this popular sports event on the pattern of admissions to São José's Hospital adult ED, located in Lisbon's city centre. This ED is integrated in a major tertiary care centre, its catchment area encompassing the city's historical centre alongside with Lisbon's eastern and northeastern districts. In São José's ED the Manchester Triage System (MTS) is in use. The MTS is employed in many emergency centers around the world, to rank the urgency level of patient visits. These levels are stratified according to a nurse-operated system, through the use of flow-charts of signs and symptoms based on problems presented at admission. ${ }^{13}$

Our goal was to monitor patient admission numbers and severity of clinical presentations in this ED during and after Sporting vs. Benfica matches, in order to determine if there was any variation in these figures between match days and 'regular' days.

\section{MATERIAL AND METHODS}

ED data from the 2008-2011 period, stored in digital records, was provided by the Hospital's Statistics Department. This data was subjected to a retrospective analysis, directed at gathering admission data for periods in which the afore-mentioned matches took place. The periods studied had a total duration of 24 hours each, which were further divided into match and post-match time frames. Match time frames had a 3.5-hour extent, comprising 45 minutes before kick-off, whole regular match time (90 minutes), 30 minutes for half-time break and extra-time, and 45 minutes after the expected final whistle. Postmatch time frames spanned the following 20.5 hours. Data related to intervals of the same length, similar day time and corresponding weekday in the previous year, was used as non-match (regular day) controls. (Example: for a 24-hour period during and after a match taking place on the last Saturday in November 2011, data related to a similar period on the last Saturday in November 2010 would be considered for control). Admission numbers were grouped according to the triage levels as assigned by the MTS in a subset of categories 1-3 (red-yellow: resuscitation, emergent and very urgent) and another subset of categories 4-5 (greenblue: urgent and non-urgent). Match day and corresponding non-match day samples were paired with each other, both in number of total admissions, and in number of triage subsets admissions. The data was then analyzed using the Wilcoxon test for paired samples (R Foundation for Statistical Computing, Vienna, Austria 2011). ${ }^{14}$ Statistical relevance was considered for $p$ values below 0.1 .

\section{RESULTS}

There were a total of 7 Portuguese First League matches between Benfica and Sporting during the 4-year period which was the object of our research. All of these matches took place in either one of the two respective home stadiums in Lisbon and were broadcast live on television. A total of 14 relevant periods ( 7 match days and 7 nonmatch days) was scrutinized, comprising a total of 5681 admissions. Of these, 4582 were triaged with the MTS. Non triaged patients were either directly admitted for acute coronary syndrome by emergency outreach vehicle teams or admitted for reevaluation consultations arranged by ED physicians. (Table 1)

During match time frames a total of 345 patients attended the ED, compared to 435 during respective control intervals, corresponding respectively to an average of 14.1 and 17.7 patients admitted per hour. This difference represents a $20.6 \%$ reduction in admissions from control intervals $(p=$ 0.06 ). On match days, the mean difference in admissions per hour triaged as green-blue (categories 4-5) was -2.1 (a reduction of $26.5 \% ; p=0.05$ ), while for admissions triaged as red-yellow (categories 1-3) the mean difference was -0.8 admissions per hour $(9.7 \%, p=0.55)$.

During post-match time frames, there were on average 122.8 patients attending the ED per hour, compared to 116.3 during controls (an increase of $5.6 \% ; p=0.44$ ). In the break-up of these admissions according to triage category subset, an average difference of +1.4 admissions per hour occurred in levels green-blue $(18.9 \% p=0.05)$ and an average difference of $+0.02(2 \% ; p=0.80)$ occurred in levels red-yellow. (Fig. 1)

\section{DISCUSSION}

Although bearing modest significance, our findings seem to concur with most of published evidence, pointing to a decline in the demand for emergency care during major sporting events. ${ }^{1-8}$ Furthermore, it suggests there might be an ensuing increase in this demand in the hours that follow such events, at least as far as less severe presentations are concerned.

This drop in admissions phenomenon has been described to occur both in ED's in close and distant geographical proximity of the actual sports event.2,4-8 This fact rules out the possibility of proximity being the sole determinant on the admission profile through physical presence of public in stadiums and sports venues. As all matches had live TV coverage, and as our ED is located approximately $6.2 \mathrm{~km}$ and $6.4 \mathrm{~km}$ from the two stadiums where the matches take 
Table 1 - Number of admissions during match and post-match time frames $(n=5861)$. Categories 1-3 are MTS levels red-yellow and 4-5 are green-blue.

\begin{tabular}{|c|c|c|c|c|c|c|c|c|}
\hline & Match Time F & & & & Post-match T & Frame & & \\
\hline $\begin{array}{l}\text { Triage } \\
\text { Urgency Level }\end{array}$ & $\begin{array}{c}\text { Categories } \\
1-3\end{array}$ & $\begin{array}{c}\text { Categories } \\
4-5\end{array}$ & Not triaged & Total & $\begin{array}{c}\text { Categories } \\
1-3\end{array}$ & $\begin{array}{c}\text { Categories } \\
4-5\end{array}$ & Not triaged & Total \\
\hline Match day 1 & 37 & 20 & 0 & 57 & 129 & 189 & 19 & 337 \\
\hline Control day 1 & 33 & 36 & 10 & 79 & 117 & 173 & 34 & 324 \\
\hline Match day 2 & 31 & 26 & 1 & 58 & 182 & 255 & 21 & 458 \\
\hline Control day 2 & 28 & 25 & 1 & 54 & 160 & 175 & 24 & 359 \\
\hline Match day 3 & 23 & 25 & 2 & 50 & 205 & 191 & 16 & 412 \\
\hline Control day 3 & 35 & 41 & 4 & 80 & 165 & 149 & 24 & 338 \\
\hline Match day 4 & 22 & 17 & 0 & 39 & 124 & 235 & 8 & 367 \\
\hline Control day 4 & 33 & 32 & 1 & 66 & 123 & 167 & 13 & 303 \\
\hline Match day 5 & 23 & 15 & 1 & 39 & 157 & 143 & 16 & 316 \\
\hline Control day 5 & 33 & 20 & 3 & 56 & 144 & 148 & 42 & 334 \\
\hline Match day 6 & 31 & 31 & 0 & 62 & 158 & 147 & 15 & 320 \\
\hline Control day 6 & 28 & 25 & 3 & 56 & 219 & 124 & 23 & 366 \\
\hline Match day 7 & 29 & 10 & 1 & 40 & 151 & 129 & 17 & 297 \\
\hline Control day 7 & 27 & 17 & 0 & 44 & 175 & 148 & 37 & 360 \\
\hline Match days & 196 & 144 & 5 & 345 & 1106 & 1289 & 122 & 2517 \\
\hline Control days & 217 & 196 & 22 & 435 & 1103 & 1084 & 197 & 2384 \\
\hline
\end{tabular}

Match Time Frame

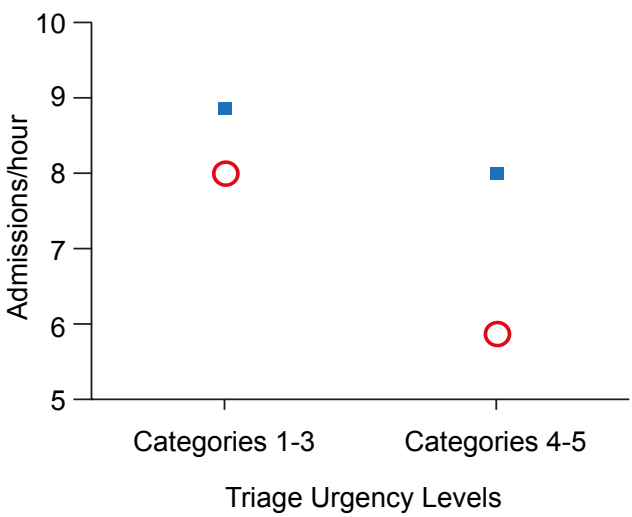

Post-match Time Frame

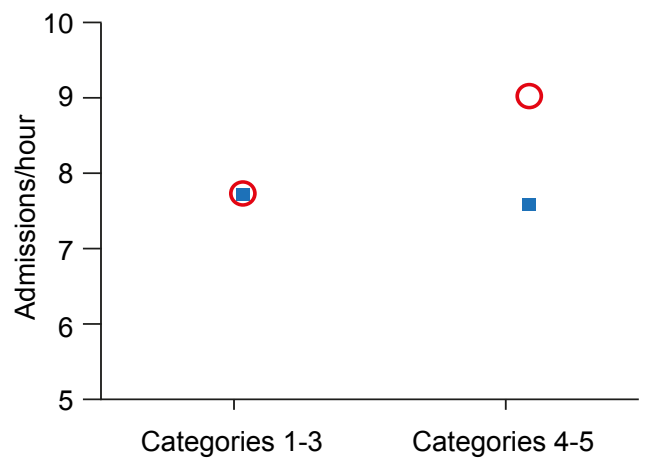

Triage Urgency Levels

Figure 1 - Variation in number of Emergency Department admissions per hour during match and post-match time frames ( $n$ / hour). Categories 1-3 are MTS levels red-yellow and 4-5 are green-blue. 
place, both stadium presence and television viewing could have had an influence in the pattern of visits to our ED. As there is another major emergency department (Santa Maria's Hospital) closer to both venues, it is possible that events involving live spectators, namely with alcoholrelated injuries and aggressions, which are described in some settings to be higher during major sporting events, were not referred to our ED. ${ }^{10-12}$ Hence, this factor could have minimized potential admissions in the immediate pre and post-match time.

Limitations of our study include the relatively short period analyzed (4 years), an unavoidable constraint since the MTS was only fully implemented in our ED in 2007. Furthermore, both match and control days used could have been distorted by confounding circumstances such as weather or other environmental conditions, which could have been responsible for variations in the admission numbers. Also, popular live and televised events, both related and unrelated to sports, could have taken place during control days, thus minimizing the impact described. Finally, care must be taken when interpreting the MTS stratified results, as this system might not be entirely reliable in the assessment of patients' clinical severity. ${ }^{15}$

This study focuses on one aspect featured in Miró's works, $^{6-7}$ whereby the severity of patients' presenting conditions was taken into account, albeit in a retrospective appreciation of clinical records. In our study, we used MTS levels as an objective stratification score of presenting patients' severity previous to their medical assessment. The findings of the afore-mentioned author and co-workers are reiterated and strengthened in our study by the use of this marker, showing that the decline and subsequent increment in visits by less urgent patients (triage levels greenblue) were considerably more pronounced than the ones observed in visits by more urgent patients (triage levels red-yellow). In fact, for both time intervals, it was the only

\section{REFERENCES}

1. Reich NT, Moscati R, Jehle D, Ciotoli M. The impact of a major televised sporting event on emergency department census. J Emerg Med. 1994;12:15-7.

2. McGreevy A, Millar L, Murphy B, Davison GW, Brown R, O'Donnell ME. The effect of sporting events on emergency department attendance rates in a district general hospital in Northern Ireland. Int J Clin Pract. 2010;64:1563-9.

3. Arevalo A, Pico J, Gimenez N. Panem et circenses or how football shows the use of emergency rooms at convenient times. Rev Calid Asist. 2012;27:123-4.

4. Moody WE, Hendry RG, Muscatello D. Were attendances to accident and emergency departments in England and Australia influenced by the Rugby World Cup Final 2003? Eur J Emerg Med. 2007;14:68-71.

5. Boyce SH. UEFA Champions League: does live television football affect attendances at accident and emergency departments? Union of European Football Associations. Eur J Emerg Med. 2002;9:77.

6. Miro O, Sanchez M, Borras A, Milla J. Football, television and emergency services. Med Clin. 2000;114:538-9.

7. Miro O, Sanchez M. Football and Rugby (... and other sport events?) emergency department attendances. Eur J Emerg Med. 2009;16:58.

8. Redelmeier DA, Vermeulen MJ. Emergency department visits during an Olympic gold medal television broadcast. Open Med. 2011;5:e112-9.

9. Perez-Ciordia I, Catalan Fabo F, Zalacain Nicolay F, Barriendo triage subset where the difference in admission volume was significant. These results seem to attest to the empirical impressions of ED staff that a lower number of less urgent patients come for emergency care during major sports events. A possible explanation could be that some of these patients might be capable of deferring their visits to the ED according to personal convenience. Improved accessibility to primary care services could potentially provide effective responses for such visits, thus satisfying patients' needs more rationally. Furthermore, awareness campaigns could play a role in informing the public about the specific mission and capabilities of different health services.

\section{CONCLUSIONS}

During major sports events, there seems to be a reduction in the number of patients seeking care in the ED, particularly those presenting with less severe conditions. Some of these patients appear to defer their ED visits to the hours following the above-mentioned events.

These findings can be taken into account in the general provision and organization of both hospital and primary acute care services.

\section{ACKNOWLEDGEMENTS}

The authors would like to acknowledge the valuable support provided by Sérgio Pedreiras and Pedro Piloto from Central Lisbon's Hospital Centre Statistics Department, in providing the data needed for this study. A special thanks to Francisco Farrajota for sharing his wise social-behavioral insights.

\section{CONFLICTS OF INTEREST}

None stated.

\section{FUNDING SOURCES}

None stated.

Antonanzas M, Solaegui Diaz de Guerenu R, Guillen Grima F. Profile of the emergency demand and influence of televised soccer games on an extra-hospital center in the Tafalla health care district, Navarre, Spain. Rev Esp Salud Publica. 2003;77:735-47.

10. Sivarajasingam V, Moore S, Shepherd JP. Winning, loosing and violence. Inj Prev. 2005;11:69-70.

11. Quigg Z, Hughes K, Bellis MA. Effects of the 2010 World Cup footbal tournament on emergency department assault attendances in England. Eur J Public Health. 2013;23:383-5.

12. Mattick AP. The Football World Cup 1998: an analysis of related attendances to an accident and emergency department. Scott Med J. 1999;44:75-6.

13. Ganley L, Gloster AS. An overview of triage in the emergency department. Nurs Stand. 2011;26:49-56.

14. Core Team. A language and environment for statistical computing. R Foundation for Statistical Computing. 2012 Vienna, Austria ISBN 3-900051-07-0. [consulted Ano Mês Dia]. Disponível em: http://www.Rproject.org.

15. van der Wulp I, van Baar ME, Schrijvers AJ. Reliability and validity of the Manchester Triage System in a general emergency department patient population in the Netherlands: results of a simulation study. Emerg Med J. 2008;25:431-4. 


\section{The Impact of the Lisbon Football Derby on the Profile of Emergency Department Admissions}

Acta Med Port 2014:27:700-703

Publicado pela Acta Médica Portuguesa, a Revista Científica da Ordem dos Médicos

Av. Almirante Gago Coutinho, 151

1749-084 Lisboa, Portugal.

Tel: +351218428215

E-mail: submissao@actamedicaportuguesa.com

www.actamedicaportuguesa.com

ISSN:0870-399X | e-ISSN: 1646-0758

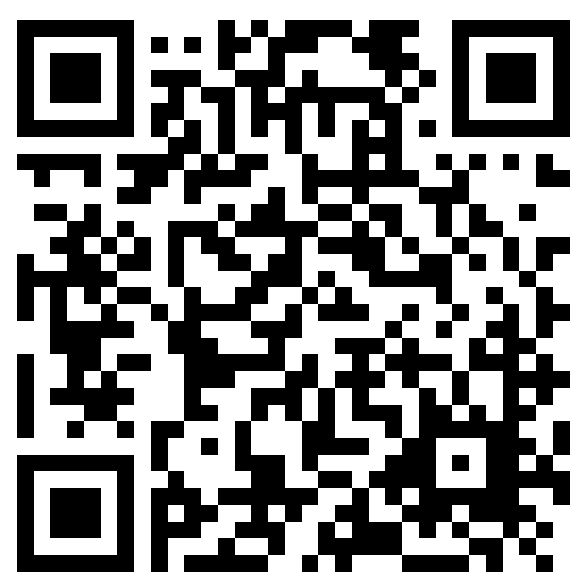

